\title{
Incidence of heartrot in harvest-age Acacia mangium in Indonesia, using a rapid survey method
}

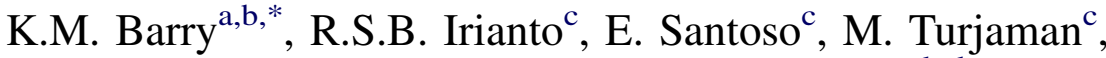

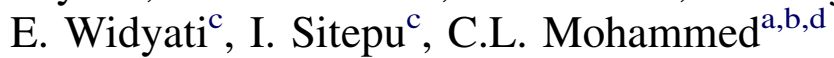 \\ ${ }^{a}$ School of Agricultural Science, University of Tasmania, Private Bag 54, Hobart 7001, Tasmania, Australia \\ ${ }^{\mathrm{b}}$ CRC for Sustainable Production Forestry, Private Bag 12, Hobart 7001, Tasmania, Australia \\ ${ }^{\mathrm{c}}$ Microbiology Laboratory, Forest and Nature Conservation Research and Development Centre, Jl. Gunung Batu No. 5, Bogor, West Java, \\ Indonesia \\ ${ }^{\mathrm{d} C S I R O}$ Forestry and Forest Products, Private Bag 12, Hobart 7001, Tasmania, Australia
}

Received 1 September 2003; accepted 13 October 2003

\begin{abstract}
The potential to use plantation-grown Acacia mangium for solid-timber products is limited by heartrot, caused by decay fungi. A rapid method of surveying logs stacked in the plantation following harvest was developed which is an alternative to timeconsuming whole tree destructive assessments. Logs were randomly chosen from the stacks using a transect method, the cutends of the logs were assessed (2199 logs in total) and heartrot severity was scored on a 1-4 scale. Surveys of harvest-age $A$. mangium were completed in five Indonesian locations to assess heartrot incidence and severity. The incidence of heartrot in the main stem was significantly different between some regions, ranging from $6.7 \%$ in East Kalimantan up to $46.7 \%$ in West Java. The proportion of each defect type (1-4) did not show a consistent trend across the sites. A combination of differences between plantation management (e.g. pruning), age and climate in these five regions explain the differences in heartrot incidence and severity.

(C) 2003 Elsevier B.V. All rights reserved.
\end{abstract}

Keywords: Decay; Fungi; Plantation; Disease management; Sustainability; Survey methodology

\section{Introduction}

Timber production from native forests in many SE Asian countries is considered to be unsustainable and this is particularly so for Indonesia (Sist et al., 1998; Rimbawanto, 2002). Indonesian forests have been reduced in total area by approximately $40 \%$ in the past 50 years (Holmes, 2002). Deforestation is continuing due to logging, both legally and illegally, for

\footnotetext{
*Corresponding author. Fax: +61-3-62267901.

E-mail address: karen.barry@ffp.csiro.au (K.M. Barry).
}

timber (Casson and Obidzinski, 2002), conversion to agricultural land and urban development. Availability of native forest for timber production is also declining due to the creation of protected areas and reserves by the Indonesian Government, especially since the early 1970s (Mishra, 1994). Plantations present one option for Indonesia to have a sustainable timber industry into the future.

Indonesian plantations of fast-grown species with short rotations have dramatically increased in the past 15 years and currently total nearly 1 million ha (Rimbawanto, 2002). Acacia mangium accounts for 
approximately $80 \%$ of these plantations and is planted mainly in Sumatra but also in some parts of Kalimantan. It is utilised primarily for pulp and secondly for medium density fibreboard (MDF) or particleboard. However, some companies are investigating its potential for solid-timber production in Indonesia (Gales, 2002).

Recent surveys to evaluate diseases of tropical Acacia plantations have concluded that heartrot, root rot and phyllode rust are the main threats (Old et al., 2000). Heartrot has been observed in most of the countries in which A. mangium has been planted, including Malaysia (Mahmud et al., 1993; Zakaria et al., 1994; Ito and Nanis, 1994; Ito, 2002), Thailand, Vietnam, Papua New Guinea, Bangladesh (Basak, 1997), India (Mehotra et al., 1996) and Indonesia (Old et al., 2000). Heartrot is usually associated with older trees, but it occurs from the age of 2 years in $A$. mangium (Lee, 2002) because heartwood forms early. Heartrot can dramatically decrease timber volume and quality (Lee, 2002). In Peninsular Malaysia, a volume loss of up to $17.5 \%$ of the merchantable timber of $A$. mangium has been reported as a result of heartrot (Lee et al., 1988; Zakaria et al., 1994). In Sabah, the volume of timber affected by decay was up to $18.1 \%$ of merchantable volume (Mahmud et al., 1993). Heartrot presents little problem for the pulpwood industry (Gales, 2002). That is, the white-rot fungi that cause heartrot preferentially remove lignin and it is this component that must be removed by chemical treatment for pulp production.

Heartrot incidence of $A$. mangium has been reported from 57 to $98 \%$ in 2- and 8-year-old trees, respectively, in Peninsular Malaysia (Zakaria et al., 1994). In Sabah the average incidence of heartrot was $35.5 \%$ from 6 to 9 years (Mahmud et al., 1993) and was a maximum of $50 \%$ in a different study of 9-year-old trees (Ito and Nanis, 1994). In Bangladesh heartrot incidence ranged from 49 to $58 \%$ in different regions (Basak, 1997). To evaluate heartrot incidence of $A$. mangium, most surveys to date have utilised destructive methods. Of five major studies, the merchantable stem length was sectioned into $1 \mathrm{~m}$ logs and then each $\log$ was sliced longitudinally to allow detection and quantification of heartrot (Mahmud et al., 1993; Zakaria et al., 1994; Ito and Nanis, 1994; Basak, 1997; Ito, 2002). While these methods are extremely valuable for gaining exact measures of heartrot and understanding paths of fungal entry into the stem (Lee et al., 1988; Mahmud et al., 1993; Ito and Nanis, 1994, 1997), they are labour intensive. This necessitates that replicate tree numbers within treatments are reasonably low, for example, 5-6 trees per 13 plantations in Bangladesh (Basak, 1997) or 10 trees per 20 plots of different age in Sabah (Mahmud et al., 1993). Also, following sectioning and slicing, the logs may not be useable by the forest industries. For regular monitoring, a quicker method of heartrot survey is desirable.

In this paper, we present heartrot survey results from A. mangium plantations in five regions of Indonesia. This includes three regions of Sumatra, one in West Java and one in East Kalimantan (the latter being the only region where heartrot has been previously surveyed in Indonesia; Maurits et al., 2001). Our main aims were to develop a quick method of heartrot survey, confirm that heartrot was prevalent in Indonesian plantations and obtain an indication of incidence in these different regions. This study will provide a basis for more detailed research on $A$. mangium heartrot in Indonesia, which aims primarily to provide management solutions.

\section{Methods}

\subsection{Site details}

Five sites were surveyed in Indonesia (Table 1), covering the major areas where A. mangium is grown. As surveys were completed in a number of compartments within one plantation region, approximate latitude and longitudes have been provided. Similarly, a range of altitudes is provided for each region (Table 1). Management practice in each area grown for pulp is typically to single the trees at 3-6 months of age. Only in the West Java region did further management occur, including pruning and thinning.

All soils are from the Ultisol order (US classification system) which are saturated with water at some time of the year or artificially drained and have features associated with wetness, for example, mottles (USDA, 1990). Yellow-red or yellow-white podsolics are a general terminology for these soils and they correspond with the udult suborder of the Ultisols (Siregar et al., 1999). The Ultisols are typically acidic and poor in fertility. 
Table 1

Details of five survey regions in Indonesia

\begin{tabular}{|c|c|c|c|c|c|}
\hline & West Java & South Sumatra & Jambi & Riau & East Kalimantan \\
\hline Latitude and longitude (approx.) & $6^{\circ} 20^{\prime} \mathrm{S}, 106^{\circ} 20^{\prime} \mathrm{E}$ & $3^{\circ} 30^{\prime} \mathrm{S}, 104^{\circ} 10^{\prime} \mathrm{E}$ & $1^{\circ} 40^{\prime} \mathrm{S}, 103^{\circ} 30^{\prime} \mathrm{E}$ & $0^{\circ} 50^{\prime} \mathrm{N}, 101^{\circ} 30^{\prime} \mathrm{E}$ & $0^{\circ} 20^{\prime} \mathrm{S}, 117^{\circ} 00^{\prime} \mathrm{E}$ \\
\hline Altitude (m a.s.l.) & $75-323$ & $50-60$ & 50 & $27-88$ & $50-200$ \\
\hline Total annual rainfall $(\mathrm{mm})$ & 3000 & 2900 & 1163 & 2400 & 2000 \\
\hline Soil types & Yellow-red podsolic & Yellow-red podsolic & $\begin{array}{l}\text { Psammentic } \\
\text { Hapludult }\end{array}$ & $\begin{array}{l}\text { Yellow-red podsolic } \\
\text { and yellow-white } \\
\text { podsolic }\end{array}$ & $\begin{array}{l}\text { Typic Hapludults and } \\
\text { Typic Kanhapludults }\end{array}$ \\
\hline Original vegetation & $\begin{array}{l}\text { Paraserianthes falcataria, } \\
\text { Shima sp. (plantation) }\end{array}$ & $\begin{array}{l}\text { Ulang-ulang } \\
\text { (Imperata } \text { sp., grassland) }\end{array}$ & Forest & Forest & Forest \\
\hline Seed source & PNG and Subanjeriji & Subanjeriji & $\begin{array}{l}\text { Claudie River } \\
\text { (Queensland, } \\
\text { Australia) }\end{array}$ & Australia and PNG & Subanjeriji \\
\hline $\begin{array}{l}\text { Rotation surveyed } \\
\quad \text { (current rotations) }\end{array}$ & $1(1)$ & $1(1-2)$ & $1(1-2)$ & $2(1-3)$ & $2(1-2)$ \\
\hline Harvest-age (years) & 8 (3-year-old thinnings) & 8 & 8 & $7-8$ & 6 \\
\hline Main product & Timber for furniture & Pulp & Pulp & Pulp & MDF and pulp \\
\hline Survey date & November 2001 & November 2001 & November 2001 & October 2001 & October 2002 \\
\hline $\begin{array}{l}\text { Total number of logs surveyed/ } \\
\text { number of compartments }\end{array}$ & $99 / 2^{*}$ & $400 / 2$ & $300 / 3$ & $800 / 4$ & $600 / 3$ \\
\hline
\end{tabular}

* One compartment is 3-year old thinnings.

\subsection{Survey method}

At all sites except West Java, logs were surveyed during harvest operations at the end of the rotation, generally at age 8 , but at age 6 in East Kalimantan (Table 1). In West Java, some trees were harvested at age 8 (60 trees), and others were surveyed at age 3 during thinning (39 trees). The number of compartments and logs per compartment surveyed (Table 1) were based on availability of harvested material during the survey period.

Log-ends were assessed while logs were stacked after harvest. Typically, ca. $100 \operatorname{logs}$ were in each pile and 3-4 logs could have been derived from one individual tree. For example, in East Kalimantan, logs were ca. $3.5 \mathrm{~m}$ long and 3-4 logs of this length were produced from an individual tree. Therefore, $\operatorname{logs}$ in the piles were not uniform in size and could have come from a number of positions in the tree. The logs chosen to assess from each log pile were selected randomly by using a line transect (a piece of string placed horizontally at random), which typically selected $10-15$ logs.

Since A. mangium wood discolours rapidly upon cutting, logs were assessed as soon as possible after harvest. Discolouration related to heartrot can appear similar to oxidative discolouration, therefore this is a potential source of confusion. Also, care was taken to correctly differentiate juvenile wood from heartrot, as both can appear very similar. Juvenile wood can have a rough, fibrous appearance similar to heartrot but is generally more uniform in shape and no discolouration is associated with it. The diameter of each selected log was measured and if a heartrot-related defect was observed this was categorised on a 1-4 scale (Table 2) and the maximum diameter measured. Logs with no heartrot were scored as 0 . Where more than one defect type was present on one log-end the highest rating was recorded and the widest point of the total defect was recorded. Sometimes the cut-face of a $\log$ would intersect with a branch and if heartrot was present in the centre of the branch, this was recorded separately. This was not done for the Jambi or West Java sites.

Table 2

Heartrot ratings used during survey

\begin{tabular}{ll}
\hline Rating & Description \\
\hline 1 & Only discolouration, no decay present \\
2 & Some decay present (slightly rough surface) \\
& but generally sound \\
3 & Advanced decay, not sound (fibrous and soft decay) \\
4 & Very advanced decay with hollows \\
\hline
\end{tabular}




\subsection{Statistical analysis}

The complete data set for heartrot incidence was analysed by an ANOVA (SAS for Windows Version 8; SAS Institute, 1999) where heartrot ratings 0-4 were treated as continuous data. Although the data was nonnormal due to the large counts of 0 , the central limit theorem states that as the sample size, $n$, approaches infinity the distribution of the sample mean approaches normality, which occurred in this case. Attempts to normalise the data (log of class plus 1$)$ did not alter the outcomes of the analysis.

Pair-wise comparisons were performed with a Z-test, for example, to reveal which plot to plot differences were significant. This test was also used to compare the harvest-aged to thinned trees from West Java.

\section{Results}

\subsection{Heartrot incidence and severity}

Total heartrot incidence (rating 1-4 combined) of harvest-age A. mangium varied substantially with site (Table 3). The ANOVA revealed that although there were fewer replicates from the West Java survey $(n=60$ for the 8 -year-old logs), this region had significantly higher total heartrot incidence $(46.7 \%)$ compared to the other regions except Jambi. Provenances of Riau, South Sumatra and East Kalimantan were not significantly different from each other, even though East Kalimantan (6.7\% total incidence) had ca. 2.4 and 1.7-fold less heartrot incidence than Riau and South Sumatra, respectively. At three sites, heartrot
Table 3

Combined heartrot incidence (rating 1-4) as a percentage of total logs surveyed, present in either the main stem or branch

\begin{tabular}{lcclll}
\hline & Riau & $\begin{array}{l}\text { South } \\
\text { Sumatra }\end{array}$ & $\begin{array}{l}\text { East } \\
\text { Kalimantan }\end{array}$ & Jambi & $\begin{array}{l}\text { West } \\
\text { Java }^{*}\end{array}$ \\
\hline Branch & 1.3 & 6.0 & 4.3 & NS & NS \\
Main stem & $15.9^{\text {a,b }}$ & $11.3^{\text {a }}$ & $6.7^{\mathbf{a}}$ & $35.3^{\mathbf{b}, \mathbf{c}}$ & $46.7^{\mathbf{c}}$ \\
\hline
\end{tabular}

NS: Not surveyed.

a ,b,c Values followed by the same letter are not significantly different $(P=0.0134)$.

* Data for harvest-age logs only.

defect was also assessed in branches if they were present on the selected logs. In South Sumatra and East Kalimantan, the incidence of heartrot detected in branches was substantial, representing at least an additional $50 \%$ of heartrot to that detected from the main stem (Table 3 ).

The proportion of each defect type (1-4) did not show a consistent trend in all sites (Fig. 1). For example, proportions were reasonably equal between each type for East Kalimantan, while defect type 1 and 2 were dominant for Jambi and West Java.

A comparison between a small number of harvestage and thinned trees was made at the West Java site. There was significantly more heartrot detected in the thinned trees, which was attributed mainly to higher levels of rating 1 and 3 heartrot (Table 4).

\subsection{Heartrot diameter}

Log and defect diameter data were averaged according to which class of defect was observed, to determine if there was a relationship between tree growth

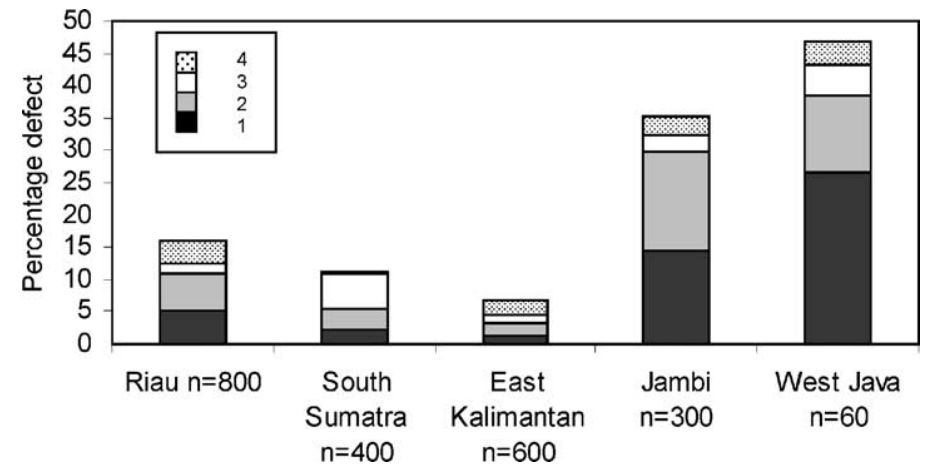

Fig. 1. Percentage of logs in each defect class (1-4) for the five survey sites. 
Table 4

Heartrot percentage detected in thinned and harvest-age trees in West Java

\begin{tabular}{lll}
\hline Rating & Thinned & Harvest-age \\
\hline 0 & 15.4 & 53.3 \\
1 & 43.6 & 26.7 \\
2 & 12.8 & 11.7 \\
3 & 20.5 & 5.0 \\
4 & 7.7 & 3.3 \\
Total 1-4 & $84.6^{\mathrm{a}}$ & $46.7^{\mathbf{b}}$ \\
$\mathrm{n}$ & 39 & 60 \\
\hline
\end{tabular}

${ }^{\mathrm{a}, \mathbf{b}}$ Values are significantly different $(P=0.0003)$.

and defect rating or size (Fig. 2). In general, there was no consistent relationship between log size and the defect rating. Also, there was no consistent trend in the defect diameter according to defect rating.

Average log diameter

Average defect diameter

\section{a. Riau}

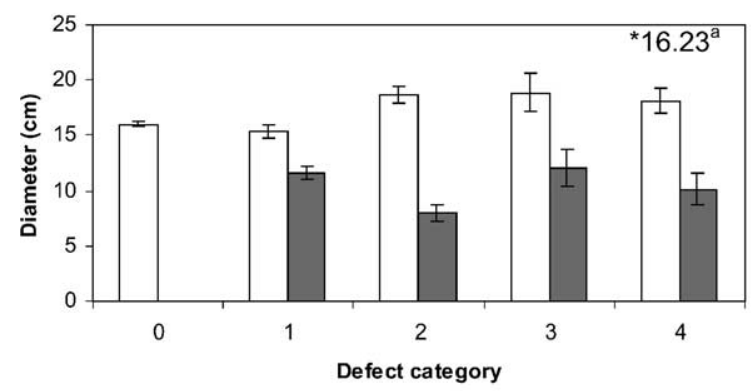

\section{c. South Sumatra}

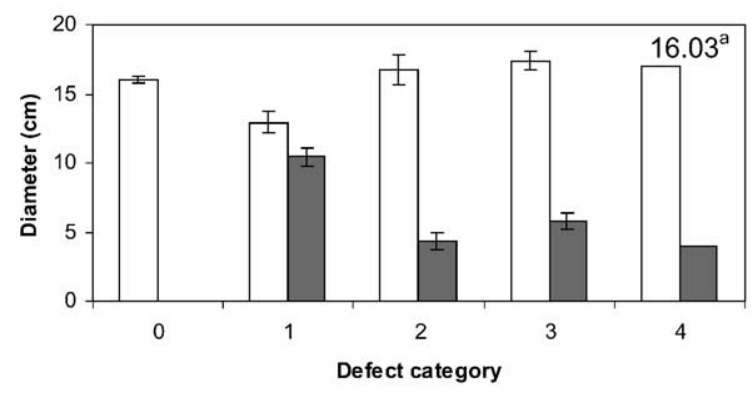

The proportion of the log diameter that was affected by heartrot was in some cases over $50 \%$, especially for Riau and Jambi (Fig. 2). Average defect diameters of ca. $10 \mathrm{~cm}$ were common for Riau and Jambi, but were considerably less for South Sumatra and East Kalimantan.

\section{Discussion}

Heartrot incidence of the main stem was varied between different regions of Indonesia (Table 3). East Kalimantan and South Sumatra were associated with the lowest heartrot incidence (Table 3) and the lowest average defect sizes (Fig. 2). Less heartrot incidence would be expected for the East Kalimantan site, mainly because the trees were 6 years old compared

\section{b. Jambi}

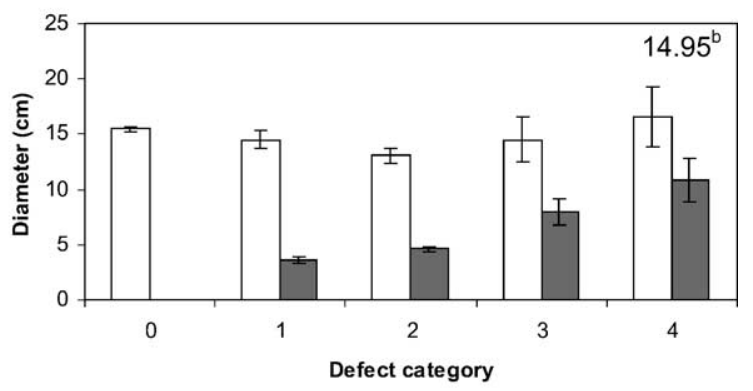

d. East Kalimantan

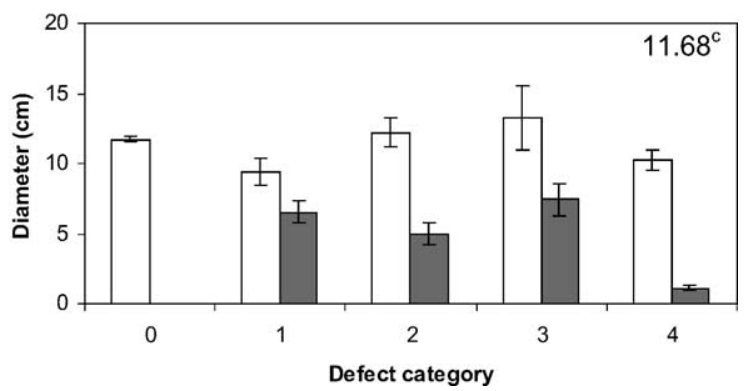

Fig. 2. (a)-(d) Comparison of average log diameter $(\mathrm{cm} \pm$ S.E.) with defect diameter $(\mathrm{cm} \pm$ S.E.) for all defect categories at four sites. Logs having defect associated with branches were excluded from this analysis and classed as 0 defect. *: Average diameter of all logs; letters indicate whether values are significantly different. 
to 8 years old at all other sites. This age-related trend has been evident in other studies of A. mangium, with positive correlations between heartrot incidence and tree age (Zakaria et al., 1994) as well as between heartrot diameter and tree diameter (Basak, 1997). A relationship between heartrot diameter and tree diameter was not apparent in this study. The results from the Riau site indicate that the diameter of the logs not affected by heartrot (category 0 ) is significantly lower than the logs with category 2-4 heartrot defect, but this trend is not consistent for the other sites (Fig. 2). This may indicate that the infection biology of $A$. mangium trees in Riau is different to the other sites. That is, trees may have either become infected with heartrot at later ages or lower down the stem (in both cases larger log diameter would be expected) than other regions.

Apart from tree age, other factors such as climate and management practices may influence heartrot incidence and spread. For example, the length of the dry season may have an effect on branch shedding and hence fungal entry (Lee and Arentz, 1997). East Kalimantan has a short dry season between June and July (S. Maurits, pers. commun.). On the basis of rainfall related theories of heartrot development (Lee and Arentz, 1997), East Kalimantan would in fact be expected to have higher heartrot incidence than areas with a more prolonged dry season, such as South Sumatra, which has a dry season from May to September (Siregar et al., 1999).

The fact that heartrot incidence at Jambi and West Java was significantly higher than the other sites (Table 3) may be explained by a number of factors. At the West Java plantations, trees are grown for furniture timber and most sites are pruned and thinned during the rotation. Both practices lead to a great number of wounds that can be readily invaded by heartrot fungi. The fact that the younger thinned trees had a higher incidence of heartrot than the older harvested trees may be because trees with large wounds were preferentially harvested for thinning. At Jambi, the different seed source may be related to higher heartrot incidence, as provenance has been suggested to affect heartrot susceptibility (Ito and Nanis, 1994). Since heartrot is commonly associated with invasion of dead or broken branches (Lee et al., 1988; Mahmud et al., 1993; Ito and Nanis, 1994, 1997; Lee, 2002) provenance differences in branching may have an influence on heartrot incidence. There is much potential for heartrot incidence to be reduced by utilising A. mangium trees which have been bred for single stems, small branches and early branch shedding (Nikles et al., 1988; Arnold and Cuevas, 2003). The Jambi plantations were derived from Claudie River seed (Table 1) which has not been shown to have particularly poor form compared to other provenances (Arnold and Cuevas, 2003).

Previous surveys using destructive methods of analysis have detected heartrot incidence of at least 35\% in Sabah (Mahmud et al., 1993) and up to $98 \%$ in Peninsula Malaysia (Zakaria et al., 1994). These results are generally higher than those found in our survey and it is possible that there are real differences in incidence between the various studies. For example, seed stock has improved markedly in the 10 years between these Malaysian studies and our current Indonesian surveys (C. Harwood, pers. commun.). Alternatively, the differences in incidence could be due to the different survey methods and our results may be an underestimation of heartrot incidence compared to the destructive studies. This is possible, given that our method examined only one cross-section of each $\log$ (although we surveyed a larger number of logs). As such, it is not possible to directly compare absolute levels of heartrot from this survey with surveys conducted by other methods. Surveys by Maurits et al. (2001) found volume losses of between 0.72 and $14.14 \%$ in A. mangium in East Kalimantan; results which are also difficult to correlate with our data. Options to correlate the data include completing thorough destructive analysis of a sub-sample of logs using methods of previous studies, following survey of the same logs with the rapid method.

The vast difference in heartrot incidence levels detected in Indonesia has varied implications for potential solid-wood production. That is, the incidence in East Kalimantan is low and therefore, theoretically, if this trend is common in the plantations in this region, solid-timber production could be viable. However, the results from Jambi indicate that there may be a greater problem with heartrot and solid-timber recovery would be less. Rotation length also needs to be incorporated into any consideration of solidtimber production, because $A$. mangium would need to be harvested at age 10-15 years to be used as saw logs or peeler logs (Gales, 2002). Over this rotation length, heartrot incidence is likely to increase considerably. 
In conclusion, this rapid survey method achieved the aims intended; to confirm that heartrot is prevalent in Indonesia and compare the incidence between different areas of Indonesia. This rapid method could prove to be useful for monitoring heartrot incidence at new sites or with changes in plantation management. It should be noted that most of the plantations surveyed in this study were being managed for pulp and as such pruning was not practised. For the production of solid timber, A. mangium will require pruning which will slow early growth substantially (Tuomela et al., 1996) and result in a source of wounds which will be invaded by heartrot fungi. Therefore, while heartrot incidence was low in some regions (e.g. East Kalimantan) this is likely to become much higher if pruning occurs and if rotation length is increased. Areas of research that are currently being pursued by our group include provenance differences in heartrot susceptibility and the affect of standard pruning or form pruning on growth and heartrot development.

\section{Acknowledgements}

Dr. Lee Su See (FRIM, Kuala Lumpur) assisted with the development of a "photo guide" for different heartrot levels and provided other valuable advice. Dr. Eko Hardiyanto (Gadja Mada University, Yogyakarta) and Ken Gales (formerly PT. Barito Pacific, Jakarta) also provided advice on practical survey procedures. We are thankful to all plantation companies and staff for access and assistance during the survey period. Assistance with statistical analysis was provided by David Ratkowsky. The paper was improved by comments from Dr. Lee Su See and Christian Cossalter (CIFOR) and two other reviewers.

\section{References}

Arnold, R., Cuevas, E., 2003. Genetic variation in early growth, stem straightness and survival in Acacia crassicarpa, A. mangium and Eucalyptus urophylla in Bukidnon Province, Philippines. J. Trop. For. Sci. 15 (2), 332-351.

Basak, A.C., 1997. Heart rot of Acacia mangium in Bangladesh. Indian J. For. 20, 61-66.

Casson, A., Obidzinski, K., 2002. From new order to regional autonomy: shifting dynamics of "illegal" logging in Kalimantan, Indonesia. World Dev. 30, 2133-2151.
Gales, K., 2002. Heartrot in forest plantations-significance to the wood processing industry. In: Barry, K. (Ed.), Heartrots in Plantation Hardwoods in Indonesia and Australia. ACIAR Technical Report 51e. CSIRO Publishing, Canberra, pp. 18-21.

Holmes, D., 2002. Indonesia: where have all the forests gone? Environment and social development, east Asia and Pacific region. Discussion Paper. The World Bank, Washington, 38 pp.

Ito, S., Nanis, L.H., 1994. Heartrot of Acacia mangium in SAFODA plantations. Sabah Reafforestation Technical Development and Training Project, Study Report. Chin Chi Printing Works, Sabah, $52 \mathrm{pp}$.

Ito, S., Nanis, L.H., 1997. Survey of heartrot on Acacia mangium in Sabah, Malaysia. Jpn. Agric. Res. Quart. 31, 65-71.

Ito, S., 2002. The infection of heart rot and disease severity on several Acacia species in SAFODA plantations. Study Report of SAFODA-JICA Project, $16 \mathrm{pp}$.

Lee, S.S., Arentz, F., 1997. A possible link between rainfall and heartrot incidence in Acacia mangium. J. Trop. For. Sci. 9, 441448.

Lee, S.S., Teng, S.Y., Lim, M.T., Kader, R.A., 1988. Discoloration and heartrot of Acacia mangium Willd.-some preliminary results. J. Trop. For. Sci. 1, 170-177.

Lee, S., 2002. Overview of the heartrot problem in Acacia-gap analysis and research opportunities. In: Barry, K. (Ed.), Heartrots in Plantation Hardwoods in Indonesia and Australia. ACIAR Technical Report 51e. CSIRO Publishing, Canberra, pp. $18-21$.

Mahmud, S., Lee, S.S., Ahmad, H.H., 1993. A survey of heartrot in some plantations of Acacia mangium Willd. in Sabah. J. Trop. For. Sci. 6, 37-47.

Maurits, S.S., Suyadi, Wardana, W., Widodo, S., Solikin, M.N., 2001. Incidence level of Acacia mangium heart rot on forest plantation in Sumalindo Group East Kalimantan. Research Report. Research and Development Planting Division Sumalindo Group, Samarinda, 70 pp.

Mehotra, M.D., Pandey, P.C., Chakrabarti, K., Hazra, K., Sharma, S., 1996. Root and heart rots in Acacia mangium plantations in India. Indian For. 122, 155-160.

Mishra, H.R., 1994. South and southeast Asia. In: McNeely, J.A., Harrison, J., Dingwall, P. (Eds.), Protecting Nature-Regional Reviews of Protected Areas. Proceedings of the Fourth World Congress on National Parks and Protected Areas, Caracas, Venezuela, February 1992. IUCN, Gland, Switzerland, pp. 49-67.

Nikles, D.G., Harwood, C.E., Robson, K.J., Pomroy, P.C., Keenan, R.J., 1988. Management and use of ex situ genetic resources of some tropical Acacia species in Queensland. In: Turnbull, J.W., Crompton, H.R., Pinyopusarerk, K. (Eds.), Proceedings of the International Workshop on Recent Developments in Acacia Planting, Hanoi, Vietnam, October 27-30, 1997. ACIAR Proceedings No. 80. CSIRO Publishing, Canberra, pp. 184196.

Old, K.M., Lee, S.S., Sharma, J.K., Yuan, Z.Q., 2000. A Manual of Diseases of Tropical Acacias in Australia, South East Asia and India. Centre for International Forestry Research, Jakarta, $104 \mathrm{pp}$. 
Rimbawanto, A., 2002. Plantation and tree improvement trends in Indonesia. In: Barry, K. (Ed.), Heartrots in Plantation Hardwoods in Indonesia and Australia. ACIAR Technical Report 51e. CSIRO Publishing, Canberra, pp. 18-21.

SAS Institute, Inc., 1999. SAS for Windows Version 8. SAS Institute, Inc., Cary, NC, USA.

Sist, P., Nolan, T., Bertault, J.-G., Dykstra, D., 1998. Harvesting intensity versus sustainability in Indonesia. For. Ecol. Manage. 108, 251-260.

Siregar, S.T.H., Hardiyanto, E.B., Gales, K., 1999. Acacia mangium plantations in PT Musi Hutan Persada, South Sumatra, Indonesia. In: Nambiar, E.K.S., Cossalter, C., Tiarks, A. (Eds.), Proceedings of the Workshop on Site Management and Productivity in Tropical Plantation Forests, Pietermaritzburg, South Africa, February 16-20, 1998. Center for International Forestry Research, Bogor, Indonesia, pp. 39-44.

Tuomela, K., Otsamo, A., Kuusipalo, J., Vuokko, R., Nikles, G., 1996. Effect of provenance variation and singling on early growth of Acacia mangium Willd. plantation on Imperata cylindrica (L.) Beauv. dominated grassland. For. Ecol. Manage. 84, 241-249.

USDA, 1990. Keys to soil taxonomy, 4th ed. USDA SMSS Technical Monograph No. 6. USDA, Blacksburg, VA, 422 pp.

Zakaria, I., Wan Razali, W.M., Hashim, M.N., Lee, S.S., 1994. The incidence of heartrot in Acacia mangium plantations in Peninsula Malaysia. FRIM Research Pamphlet, 114, p. 15. 